\title{
Second International Symposium on the Economic and Social Costs of Substance Abuse
}

Montebello, Quebec, October 2-5, 1995

The purpose of the Second International Symposium on the Economic and Social Costs of Substance Abuse was to describe recent cost estimation studies, to review a set of guidelines for estimating the economic costs of substance abuse developed at the First International Symposium on the Economic and Social Costs of Substance Abuse, to examine the utility of cost estimates in informing policy and program development, to promote further implementation of the guidelines, to identify data needs, and to identify other steps required to expand the concept of economic cost studies to the international community. The symposium was organized by the Canadian Centre on Substance Abuse and cosponsored by the Addiction Research Foundation, the Alberta Alcohol and Drug Abuse Commission, the US Center for Substance Abuse Prevention, Canada's Drug Strategy Secretariat, the US National Institute on Drug Abuse, the US National Institute on Alcoholism and Alcohol Abuse, the Norwegian National Directorate for the Prevention of Alcohol and Drug Problems, the Royal Canadian Mounted Police, the US Substance Abuse and Mental Health Services Administration, the United Nations International Drug Control Programme and the World Health Organization.

Updated National Studies on the Costs of Substance Abuse In the first session of the symposium a set of updates on national cost estimation studies were presented. Presentations were made by Rick Harwood (USA), Jeffrey Merrill (USA), Brian Easton (New Zealand), David Collins and Helen Lapsley (Australia) and Eric Single (Canada). A general discussion on conceptual and practical issues in cost estimation followed the updates. David Collins informed the group that a user-friendly computer program has been developed in Australia for applying the etiologic fractions developed by Dallas English and his colleagues to morbidity and mortality data. The symposium participants agreed to share resources such as computer programs and reports on the results of cost estimation studies. Alan Lopez noted that the WHO intends to expand the work conducted by Dr. Peto and Dr. Lopez on tobacco-related deaths in different countries to alcohol in the near future.

Gary Hulse and Michael Winter, 'The Quantification of Morbidity and Mortality Caused by Substance Abuse'; Sharon Pearson, Philip Jacobs and Richard Plain, 'Assessing Costs:

Substance Abuse in the Workplace'; Marlene Gyldmark and Ebbe Hansen, 'Estimating the Cost of Misuse of Psychotropic Pharmaceuticals'; Kai Pernanen, 'The Social Cost of Alcohol-Related Crime: Conceptual, Theoretical and Causal Attributions', and Serge Brochu, 'Estimating the Costs of Drug-Related Crime'.

Small Group Discussions, Research Panel and Future Plans The participants divided into three small groups to discuss the utility of cost estimates, data requirements, and future developmental steps. There followed a panel on a common framework for cost estimation, consisting of David Collins, Brian Easton, Rick Harwood, Helen Lapsley and Eric Single. In the final session of the symposium, the participants briefly reviewed plans for the future development of economic cost studies at the national level. There was a clear consensus that the CCSA should organize a third 
international symposium to take place in the first half of 1997 . The next symposium will focus on further refinements in methodology and the promotion of cost estimation studies in other countries, particularly in Europe.

A full report of the symposium summarizing the presentations and discussions is available from the Canadian Centre on Substance Abuse (75 Albert Street, Suite 300, Ottawa, Canada KIP 5E7; Internet: http://www.ccsa.ca). In addition, a set of 'International Guidelines for Estimating the Social and Economic Costs of Substance Abuse’ by E. Single, D. Collins, B. Easton, R. Harwood, H. Lapsley and A. Maynard, developed at an earlier symposium on economic cost estimation, is available from the CCSA or by downloading from the CCSA home page on the worldwide web.

Prof. Eric Single, CCSA Policy and Research Unit, University of Toronto, 100 College Street, Suite 511, Toronto, M5G 1L5 (Canada)

Tel.+1416 9781772 Fax+1 4169712679

Commissioned Papers on Selected Topics

The following commissioned papers were presented and discussed: Richard Lindblad, 'Some Policy Issues Relating to the Development of International Guidelines for Substance Abuse Social and Economic Costs'; Dallas English, D’Arcy Holman, Elizabeth Milne, KAKGER

(C)1997S. KargerAG, Basel

E-Mail karger@karger.ch Fax + 41613061234 http://www. karger. ch 